\title{
РОЛЬ МІКРООРГАНІЗМІВ, ВИДІЛЕНИХ ІЗ ПАРОДОНТАЛЬНИХ КИШЕНЬ, У ПАТОГЕНЕЗІ ГЕНЕРАЛІЗОВАНОГО ПАРОДОНТИТУ В ОСІБ 3 ЛЯМБЛІОЗНОЮ ІНВАЗІЄЮ
}

\author{
Харківський національний медичний університет, м. Харків, Україна
}

\begin{abstract}
Питання етіопатогенезу генералізованого пародонтиту хронічного перебігу у осіб з паразитарною інвазією залишаються маловивченими.

Метою роботи було вивчення ролі мікробів, виділених з пародонтальних кишень, у розвитку генералізованого пародонтиту в осіб з лямбліозом.

Матеріали і методи. Було обстежено 120 хворих на генералізований пародонтит I-II ступеня тяжкості хронічного перебігу на тлі лямбліозу (основна група). Групу порівняння склали 90 осіб з генералізованим пародонтозом I-II ступенів тяжкості хронічного перебігу без лямбліозної інвазії. Контрольна група представлена 30 особами без патології пародонта і хронічної патології інших систем, які в період обстеження вважалися практично здоровими.

Мікробіологічні дослідження включали виділення та ідентифікацію мікроорганізмів з використанням техніки аеробного й анаеробного культивування.

Статистичну обробку матеріалів проводили з використанням методів математичної статистики для аналізу отриманих даних.

Результати. Встановлено, що у мікроорганізмів, які колонізують пародонтальні кишені у хворих на генералізований пародонтит I-II ступенів тяжкості на тлі лямбліозу, присутні антигени тканинних структур пародонта.

Висновки. Мікроорганізми пародонтальних кишень $€$ не тільки індукторами банального запалення в тканинах пародонта внаслідок їх патогенних властивостей (токсиноутворення, продукції фрерментів агресії тощо), але й виступають потужним фрактором, що модифрікує силу і спрямованість вектора імунної реакції. Імунна реакція, яка за своєю природою і суттю є виключно захисним механізмом організму, здатна під впливом мікробів, що експресують тканинні антигени мімікрії, перетворюватися на чинник агресії проти власних тканин.
\end{abstract}

КЛЮЧОВІ СЛОВА: генералізований пародонтит, мікроорганізми, антигени мімікрії, лямбліоз.

Проблема лікування генералізованого пародонтиту (ГП) не втрачає своєї актуальності. Незважаючи на існування досить ефективних препаратів, у тому числі протимікробних, які дозволяють придушити як місцеву, так і генералізовану інсрекцію, при лікуванні ГП все ж не вдається домогтися бажаного позитивного довгострокового результату. Наблизитися до вирішення даної проблеми дозволяють численні дослідження в галузі пародонтології, що проводяться на цей час в усьому світі.

Питання етіопатогенезу генералізованого пародонтиту (ГП) хронічного перебігу в осіб з паразитарною інвазією залишаються маловивченими. У розвитку ГП низка дослідників велику роль відводить мікробам [7], що колонізують пародонтальні кишені, характеру імунного реагування на інфекційні агенти [10], метаболічним і гормональним розладам в організмі [2], стану нервової системи [5], дії багатьох шкідливих факторів зовнішнього середовища [1].

При цьому в літературі немає відповіді, яку роль відіграють мікроби в патогенезі ГП хронічного пере-

(с) Н.М. Савєльєва, 2016 бігу, звужуючи їі, як правило, до індукції запалення. Запалення ж розглядають не як фрактор захисту та елімінації інфеекційних агентів, а як фрактор, що викликає ураження пародонта. На сьогоднішній день також не існує пояснень, чому запальний процес, індукований мікробами, викликає генералізоване ураження пародонта.

Метою цієї роботи було вивчення ролі мікробів, виділених 3 пародонтальних кишень, у розвитку ГП в осіб з лямбліозом.

Матеріали і методи. На кафредрі стоматології ХНМУ було обстежено 120 хворих на ГП І-ІІ ступенів тяжкості хронічного перебігу на тлі лямбліозу: з I ступенем тяжкості перебігу захворювання - 48 осіб і з ІІ ступенем тяжкості - 72 людини (основна група).

Групу порівняння склали 90 осіб з ГП І-ІІ ступенями тяжкості хронічного перебігу без лямбліозної інвазії (60 осіб - 3 I ступенем і 30 осіб з ІІ ступенем тяжкості захворювання).

Контрольна група представлена 30 особами без патології пародонта і хронічної патології інших систем, які в період обстеження вважали себе практично здоровими. 
3 метою виключення вікової множинності патології в досліджені групи (основну, порівняння, контрольну) включали осіб у віці 20-40 років. Критеріями виключення були хронічні захворювання внутрішніх органів, серцево-судинна патологія, хронічні захворювання нервової та ендокринної систем, аутоімунна патологія, алергічні захворювання.

Стоматологічний діагноз встановлювали пацієнтам на підставі опитування, огляду, визначення спрощеного індексу гігієни рота OHI-s (J.C. Green, J.R. Vermillion, 1964), індексної оцінки стану тканин пародонта: інтенсивність запалення тканин пародонта - PMA (G. Parma, 1960), пародонтального індексу - PI (A. Russell, 1956), кровоточивості ясенної борозни - індекс кровоточивості Muhlemann-SBI (Muhlemann, 1971), вимірювання рівня втрати зубоясенного з'єднання (мм), глибини пародонтальних кишень (мм), висоти рецесії ясен (мм) і рентгенологічного дослідження відповідно до класифікації хвороб пародонта (проф. Н.Ф. Данилевський, 1994).

Діагноз «лямбліоз» хворим з ГП встановлювали на кафредрі медичної паразитології і тропічних хвороб Харківської медичної академії післядипломної освіти МО3 України (завідувач кафедри профресор К.І. Бодня) відповідно до загальноприйнятих критеріїв і методичних вказівок.

Мікробіологічні дослідження включали виділення та ідентифрікацію мікроорганізмів 3 використанням техніки аеробного й анаеробного культивування. Забір клінічного матеріалу (наліт ясенної борозни, вміст пародонтальних кишень) проводили за допомогою стандартного стерильного тампона транспортної системи Sarstedit (Німеччина). Для подальшого культивування використовували набір поживних середовищ фрірми Bio Merieux (Франція): для аеробних і фракультативних бактерій - шоколадний агар з PVX; для анаеробних бактерій - Шедлєр агар + 5\% еритроцитів барана; для грибів - агар Сабуро 3 гентаміцином + хлорамінфенікол. Культивування матеріалу на поживних середовищах здійснювали в термостаті при температурі $37^{\circ} \mathrm{C} 3-5$ діб, анаеробних культур - мікроанаеростатах фрірми Bio Merieux. Ідентифрікацію виділених чистих культур проводили за морфолого-культуральними та біохімічними ознаками за допомогою діагностичних панелей Вio Merieux: API Staph., API Sprept, API 20E, API 20, API Candida, API 20 CAUX.

Для виявлення антигенів (АГ) мімікрії у мікроорганізмів використовували реакцію аглютинації [9], в якій реагентами були кроляча гіперімунна сироватка до АГ пародонта і патогенні грампозитивні і грамнегативні мікроорганізми (S. aureus, S. pyogenes, S. epidermidis, S. haemolyticus, Proteus, E. coli, Enterobacter aerogenes), виділені у хворих на пародонтит, а також сапрофіти, які зазвичай колонізують слизову ясен (S. mitis, S. capitis, S. salivarius). Контролем служили мікро- би, виділені з ясен хворих на гострий гінгівіт, і практично здорових осіб (ПЗО).

Для отримання гіперімунної моноспеціфрічної сироватки були використані 5 кролів породи шиншила у віці 5,5-6 місяців, вагою 2700-2800 г. Роботу 3 тваринами проводили відповідно до Європейської конвенції про захист хребетних тварин, що використовуються для дослідних та інших наукових цілей (Страсбург, 18 березня 1986 року). Усі тварини перебували в умовах утримання, які відповідали міжнародним нормам GLP.

Гіперімунізацію кролів проводили шляхом посхемного підшкірного введення АГ пародонта в наступних розрахованих за білком дозах: 50 мкг 100 мкг -150 мкг - 200 мкг - 300 мкг. Інтервал між ін'єкціями становив три дні. Для визначення титру антитіл в імунній сироватці використовували реакцію преципітації з білковими водно-сольовими тканинними АГ [9]. Отримана гіперімунна кроляча сироватка містила титр преципітинів до АГ пародонта 1:311.

Антигени пародонта отримували шляхом водносольової екстракції тканини пародонта ЗМ розчином $\mathrm{KCl}$ екстракції [8]. В імунних реакціях використовували фрракцію з молекулярною масою 80000160000. Вміст білка в екстракті становив 0,7-1,0\%.

Статистичну обробку матеріалів проводили 3 використанням методів математичної статистики для аналізу отриманих даних [4]. Зокрема, методи оцінки, за допомогою яких з певною ймовірністю зроблені висновки щодо параметрів розподілу; для визначення розбіжності між середніми значеннями використовували параметричний t-критерій Стьюдента і непараметричний Т-критерій Вілкоксона. Перевірку знайдених розбіжностей проводили на рівні значущості <0,05. Статистична обробка результатів була здійснена за допомогою Microsoft Exel 2007 і програми MedStat згідно з рекомендаціями що статистичної обробки медикобіологічних даних [3; 6].

Результати та їх обговорення. Було встановлено, що позитивна реакція аглютинації в високих титрах реєструється при використанні в реакції грампозитивних коків (S. aureus, S. pyogenes, S. epidermidis, S. haemolyticus), отриманих від хворих на ГП як з лямбліозом, так і без нього. Високі титри реакції спостерігали при використанні мікробів, виділених від хворих I та II ступенів тяжкості захворювання (табл.).

Як випливає 3 наведених даних, при II ступені тяжкості захворювання титри реакції аглютинації 3 мікробами S. aureus, S.pyogenes, S. epidermidis, S. haemolyticus хворих на ГП з лямбліозом і хворих на ГП без лямбліозу були достовірно вищими, ніж хворих на ГП І ступеня тяжкості захворювання $(p<0,05)$. Слід зазначити, що титри реакції аглютинації з грамнегативними мікробами (Proteus, E. coli, Enterobacter aerogenes) у хворих на ГП І сту- 
пеня тяжкості захворювання були в 3,2-3,5 разу нижчими, а у хворих на ГП ІІ ступеня в 5,0- 5,3 разу нижчими, ніж з грампозитивними коками (табл.).

Використання в якості реагентів сапрофрітної мікрофрлори не давало позитивну реакції аглютинації (табл.).

Отримані дані свідчать про те, що у мікроорганізмів, які колонізують пародонтальні кишені, присутні мімікрійні антигени тканинних структур пародонта. Найбільшою мірою вони представлені патогенними грампозитивними коками. Грамнегативні мікроорганізми виявляли слабку презентуючу активність АГ мімікрії.

Можна вважати, що патогенна мікрофрлора на початкових етапах захворювання здатна виступати фрактором індукції імунної реакції на АГ мімікрії і, отже, на тканинні АГ пародонта. Відсутність АГ мімікрії на сапрофрітній мікрофрлорі (S. mitis, S. capitis, S. salivarius), мабуть, пов'язано з особливістю їх фрізіології та метаболізму і нездатністю чинити патогенну дію на тканини, які вони заселяють.

Вивчення мікрофрлори, виділеної з ясенної борозни хворих на гострий гінгівіт, не виявило на патогенних коках (S. aureus, S. pyogenes, S. epidermidis, S. haemolyticus) АГ мімікрії. Реакція аглютинації 3 кролячою гіперімунною сироваткою до АГ пародонта була негативною з усіма виділеними штамами мікроорганізмів.

Також реакція гіперімунної сироватки була негативною і з мікроорганізмами, виділеними із ясенної борозни ПЗО (S. aureus, S. epidermidis, Neiseria).

Отримані дані свідчать про те, що поява АГ мімікрії на мікрофрлорі, що заселяє пародонтальні

Таблиця. Титр реакції аглютинації кролячої гіперімунної сироватки до АГ пародонта з мікроорганізмами, виділеними з пародонтальних кишень хворих на ГП I і II ступенів тяжкості хронічного перебігу захворювання на тлі лямбліозу і хворих на ГП I і II ступенів тяжкості хронічного перебігу без лямбліозної інвазії

\begin{tabular}{|l|c|c|c|c|}
\hline \multicolumn{1}{|c|}{ Мікроорганізм } & $\begin{array}{c}\text { ГП І ст. тяжкості } \\
\text { + лямбліоз }\end{array}$ & $\begin{array}{c}\text { ГП І ст. тяжкості } \\
\text { без лямбліозу }\end{array}$ & $\begin{array}{c}\text { ГП ІІ ст. тяжкості + } \\
\text { лямбліоз }\end{array}$ & $\begin{array}{c}\text { ГП ІІ ст. тяжкості } \\
\text { без лямбліозу }\end{array}$ \\
\hline S. aureus & $1: 151 \pm 16,2^{\star \star}$ & $1: 109 \pm 12,2$ & $1: 261 \pm 21,6^{\star}$ & $1: 212 \pm 21,1^{\star}$ \\
\hline S. pyogenes & $1: 147 \pm 15,7^{\star \star}$ & $1: 110 \pm 12,9$ & $1: 250 \pm 21,7^{*}$ & $1: 208 \pm 21,6^{\star}$ \\
\hline S. epidermidis & $1: 143 \pm 15,4^{\star \star}$ & $1: 105 \pm 12,6$ & $1: 244 \pm 20,9^{\star}$ & $1: 203 \pm 20,6^{\star}$ \\
\hline S. haemolyticus & $1: 149 \pm 15,7^{\star \star}$ & $1: 103 \pm 12,7$ & $1: 241 \pm 20,8^{\star}$ & $1: 201 \pm 20,5^{\star}$ \\
\hline Proteus & $1: 39 \pm 6,7$ & $1: 29 \pm 5,3$ & $1: 40 \pm 7,5$ & $1: 46 \pm 7,3$ \\
\hline E. coli & $1: 31 \pm 6,9$ & $1: 28 \pm 5,4$ & $1: 41 \pm 7,6$ & $1: 40 \pm 7,3$ \\
\hline Enterobacter erogenes & $1: 30 \pm 6,8$ & $1: 26 \pm 5,6$ & $1: 47 \pm 7,6$ & $1: 48 \pm 7,4$ \\
\hline S. mitis & 0 & 0 & 0 & 0 \\
\hline S. capitis & 0 & 0 & 0 & 0 \\
\hline S. salivarius & 0 & 0 & 0 & 0 \\
\hline
\end{tabular}

Примітки: титр реакції преципітації кролячої гіперімунної сироватки до АГ пародонта з тканинними АГ пародонта 1: 311;

0 - реакція була відсутня;

* - Р <0,05 між показниками хворих на ГП І ступеня та ГП ІІ ступеня тяжкості захворювання;

** - P <0,05 між показниками хворих ГП з лямбліозом і хворих ГП без лямбліозу.

кишені, вимагає певних умов. 3 огляду на те, що гострий гінгівіт у групи обстежених нами пацієнтів перебігав на тлі активації місцевих імунних фракторів (підвищення рівня лізоциму в 1,8 разу, секреторного IgA в 1,5 разу); а у практично здорових осіб орактори місцевого захисту відповідали середній статистичній нормі, можна констатувати, що необхідною умовою появи на патогенній мікрофрлорі АГ мімікрії у хворих на ГП є зниження місцевого імунітету і нездатність імунних фракторів ефективно пригнічувати розвиток мікробів і впливати на їх метаболізм. Хронічне запалення створює середовищну обстановку, в якій і відбувається сенсибілізація мікробів АГ навколишніх тканин. Таким чином, імунна реакція, спочатку розвиваючись на інфекційний агент, що експресує АГ мімікрії, в по- дальшому переключається на тканини, що несуть подібні антигени.

Слід зауважити, що паразитарна інвазія мала значний вплив на появу на мікробах АГ мімікрії. Титр реакції аглютинації кролячої гіперімунної сироватки з грампозитивними мікробами, виділеними від хворих на ГП І ст. тяжкості хронічного перебігу 3 паразитозами і хворих на ГП І ступеня без паразитозів, достовірно відрізнявся $(p<0,05)$, а у хворих на ГП ІІ ступеня тяжкості хронічного перебігу з лямбліозом і хворих II ступеня без лямбліозу виявляв тенденцію до відмінностей.

Раніше нами було встановлено, що у хворих на ГП хронічного перебігу з паразитозами порівняно 3 хворими без паразитозів істотно (статистично достовірно) знижений місцевий імунітет в ротовій по- 
рожнині і більш виражений дисбактеріоз. Разом 3 тим спостерігався різноманітніший видовий склад бактерій, що заселяють пародонтальні кишені, і виразніший ступінь мікробної колонізації слизових поверхонь. У сукупності ці фрактори у хворих ГП з паразитозами, безсумнівно, чинять потужніший вплив на мікробну сенсибілізацію організму, модифрікацію і спрямованість імунних реакцій і характер запалення в пародонті, ніж у хворих ГП без паразитозів.

Отримані нами дані свідчать про те, що клінічно ГП у хворих з лямбліозом перебігає тяжче, ніж у хворих без лямбліозу, в більш ранні терміни I ступінь трансорормується у ІІ ступінь тяжкості захворювання, часто набуває рис прогресуючого перебігу з розвитком запально-деструктивних процесів у тканинах пародонта.

\section{Висновки}

Мікроорганізми пародонтальних кишень $€$ не тільки індукторами банального запалення в тканинах пародонта внаслідок їх патогенних властивостей (токсиноутворення, продукції фрерментів агресії тощо), але і виступають потужним фрактором, який модифікує силу і спрямованість вектора імунної реакції. Імунна реакція, будучи за своєю природою і суттю винятково захисним механізмом організму, здатна під впливом мікробів, що експресують тканинні АГ мімікрії, перетворюватися на чинник агресії проти власних тканин.

Отримані результати свідчать про те, що мікроби пародонтальних кишень на тлі зниження місцевого імунітету здатні надавати хронічному запаленню в пародонті елементів аутоімунного процесу та сприяти генералізації запального процесу, який від самого початку виник на обмеженій ділянці пародонта.

Отримані дані підтверджують точку зору про доцільність раннього включення в протокол лікування хворих на ГП антимікробних засобів не тільки 3 метою санації порожнини рота, а й як дієвого засобу запобігання і пригнічення розвитку аутоімунних процесів.

Перспективами подальших досліджень у даному напрямку $є$ проведення експериментальних досліджень in vitro 3 визначенням можливості появи на мікроорганізмах, виділених 3 пародонтальних кишень, антигенів мімікрії щодо інших структур комплексу тканин пародонта.

\section{Список літератури}

1. Бандрівська Н. Н. Особливості клінічного перебігу, лікування та профрілактика захворювань пародонта у працівників цементного виробництва : автореф. дис. на здобуття наук. ступеня кандидата мед. наук: спец.14.01.22 I Н.Н. Бандрівська. - Львів, 2010. -16 с.

2. Борисенко А. В. Вплив захворювань пародонта на загальний стан організму / А. В. Борисенко // Здоров'я суспільства. - 2013. - № 1. - С. 32-37.

3. Гланц С. Медико-биологическая статистика [Текст] / С. Гланц. - М. : изд-во Практика, 1999. - 459 с.

4. Гмурман В. Е. Теория вероятностей и математическая статистика [Текст]. - М. : Высшее образование, 2007. - 479 с.

5. Заболотний Т. Д. Вивчення стоматологічного статусу у людей з психічними захворюваннями / Т. Д. Заболотний,

3. М. Гонта, Р. М. Гнідь, Л. Б Наугольник // Практична медицина - 2010. - № 6, Т.16. -С. 138-143.

6. Лакин Г. Ф. Биометрия [Текст] / Г. Ф. Лакин. - М. : Высш. школа, 1990. - 352 с.

7. Слобода М. Т. Фактори вірулентності пародонтопатогенної мікрофрлори як етіопатогенний фрактор розвитку пародонтиту та гінгівіту в осіб молодого віку / М. Т. Слобода // Клінічна стоматологія. - 2015. - № 1. - С. 69-74.

8. Фролов В. М. Аутоиммунная и иммунокомплексная патология у больных инсулинзависимым сахарным диабетом [Текст] / В. М. Фролов, Л. Л. Пинский, Н. А. Пересадин // Проблемы эндокринологии. - 1991. - № 5. - С. $22-24$.

9. Чернушенко Е. Ф. Иммунологические исследования в клинике : монографрия / Е. Ф. Чернушенко, К. С. Когосова. К. : Здоровья, $1978-159$ с.

10. Чумакова Ю. Г. Роль цитокинов и регуляции воспаления тканей пародонта у больных генерализованным пародонтитом / Ю. Г. Чумакова // Современная стоматология. - 2004. - № 4. - С. 60-62.

\section{References}

1. Bandrivska, N.N. (2010). Osoblyvosti klinichnoho perebihu, likuvannia ta profilaktyka zakvoriuvan parodonta u pratsivnykiv tsementnoho vyrobnytstva [Features of clinical course, treatment and prevention of periodontal diseases in cement production workers]. Candidate's thesis. Lviv [in Ukrainian].

2. Borysenko, A.V. Vplyv zakhvoriuvan parodonta na zahalnyi stan orhanizmu [The impact of periodontal disease on overall health]. Zdorovya suspilstva - Health of Population, 1, 32-37 [in Ukrainian].

3. Glants, S. (1999). Mediko-biologicheskaya statistika [Biomedical Statistics]. Moscow: Izdatelstvo Praktika [in Russian].

4. Gmurman, V.E. (2007). Teoriya veroyatnostey i matematicheskaya statistika [Theory of probability and mathematical statistics]. Moscow: Vysshee obrazovanie [in Russian].

5. Zabolotnyi, T.D., Honta Z.M., Hnid, R.M., \& Nauholnyk, L.B (2010). Vyvchenia stomatolohichnoho statusu u liudei z psykhichnymy zakhvoriuvaniamy [The study of the dental status of people with mental illness]. Praktychna medytsyna Practical Medicine, 6(16), 138-143. [in Ukrainian].

6. Lakin, G.F. (1990). Biometriia [Biometrics]. Moscow: Vysshaia shkola [in Russian].

7. Sloboda, M.T. (2015). Faktory virulentnosti parodontopatohennoi mikroflory yak etiopatohennyi factor rozvytku parodontytu ta hinhivitu v osib molodoho viku [Virulence factors parodonto-pathogenic microflora as etiopathogenic factor 
of influence of periodontitis and gingivitis in young people]. Klinichna stomatolohiya - Clinical Stomatology, 1, 69-74 [in Ukrainian].

8. Frolov, V.M., Pinskiy, L.L., \& Peresadin, N.A. (1991). Autoimmunaya I immunokompleksnaya patologiya u bolnykh insulinzavisimym sakharnym diabetom [Autoimmune and immunocomplex pathology in patients with insulin-dependent diabetes mellitus]. Problemy endokrinologii - Problems of Endocrinology, 5, 22-24 [in Russian].

9. Chernushenko, E.F., \& Kogosova, K.S. (1978). Immunologicheskiye issledovaniya v klinike: monografiya [Immunological studies in the clinic: monography]. Kiev: Zdorovya [in Russian].

10. Chumakova, Yu.H. (2004). Rol tsytokinov i regulatsii vospaleniia tkaney parodonta u bolnykh generalizovannym parodontitom [The role of cytokines and regulation of inflammation in periodontal tissues of patients with generalized periodontitis]. Sovremennaya stomatologiya - Modern Stomatology, 4, 60-62 [in Ukrainian].

\section{РОЛЬ МИКРООРГАНИЗМОВ, ВЫДЕЛЕННЫХ ИЗ ПАРОДОНТАЛЬНЫХ КАРМАНОВ, В ПАТОГЕНЕЗЕ ГЕНЕРАЛИЗОВАННОГО ПАРОДОНТИТА У ЛИЦ С ЛЯМБЛИОЗНОЙ ИНВАЗИЕЙ}

Н.Н. Савельева

Харьковский национальный медицинский университет, г. Харьков, Украина

Вопросы этиопатогенеза генерализованного пародонтита хронического течения у лиц с паразитарной инвазией до настоящего времени остаются малоизученными.

Целью этой работы было изучение роли микробов, выделенных из пародонтальных карманов, в развитии генерализованного пародонтита у лиц с лямблиозом.

Материалы и методы. Было обследовано 120 больных генерализованным пародонтитом I-II степеней тяжести хронического течения на фроне лямблиоза (основная группа). Группу сравнения составили 90 человек с ГП I-II степеней тяжести хронического течения без лямблиозной инвазии. Контрольная группа была представлена 30 лицами без патологии пародонта и хронической патологии других систем, в период обследования считавшими себя практически здоровыми.

Микробиологические исследования включали выделение и идентификацию микроорганизмов с использованием техники аэробного и анаэробного культивирования.

Статистическую обработку материалов проводили с использованием методов математической статистики для анализа полученных данных.

Результаты. Показано, что у микроорганизмов, колонизирующих пародонтальные карманы больных генерализованным пародонтитом I-ІІ степеней тяжести на фроне лямблиоза, присутствуют антигены тканевых структур пародонта.

Выводы. Микроорганизмы пародонтальных карманов являются не только индукторами банального воспаления в тканях пародонта вследствие их патогенных свойств (токсинообразования, продукции ферментов агрессии и т. д.), но и выступают мощным фрактором, модифицирующим силу и направленность вектора иммунной реакции. Иммунная реакция, будучи по своей природе и сути исключительно защитным механизмом организма, способна под влиянием микробов, экспрессирующих тканевые антигены мимикрии, превращаться в фрактор агрессии против собственных тканей.

КЛЮЧЕВЫЕ СЛОВА: генерализованный пародонтит, микроорганизмы, антигены мимикрии, лямблиоз.

\section{IMPLICATION OF MICROORGANISMS ISOLATED FROM PERIODONTAL POCKETS IN THE PATHO- GENESIS OF GENERAL PERIODONTITIS IN PATIENTS WITH GIARDIASIS}

N. N. Savel'eva

Kharkiv National Medical University, Kharkiv, Ukraine

The problems of etiopathogenesis of generalized periodontitis of chronic course in persons with parasitic infestation to the present day remain poorly studied.

Purpose. Therefore, the goal of this work was to study the role of microbes isolated from periodontal pockets in the development of generalized periodontitis in persons with giardiasis.

Materials and methods. 120 patients with generalized periodontitis of I-II severity of chronic course were examined with lambliasis (main group). The comparison group consisted of 90 people with GP of I-II severity of chronic course without giardiasis invasion. The control group was represented by 30 persons without pathology of periodontal disease and chronic pathology of other systems, which during the examination period considered themselves to be practically healthy.

Microbiological studies included the isolation and identification of microorganisms using aerobic and anaerobic cultivation techniques.

Statistical processing of materials was carried out using mathematical statistics methods to analyze the data obtained.

Results. It has been shown that antigens of periodontal tissue structures are present in microorganisms colonizing the periodontal pockets of patients with generalized parodontitis of I-II severity against the background of giardiasis. 
Conclusion. Microorganisms of periodontal pockets are not only inducers of banal inflammation in periodontal tissues due to their pathogenic properties (toxin formation, production of enzymes of aggression, etc.), but also serve as a powerful factor that modifies the strength and direction of the immune vector Reaction. The immune response, being by its nature and essence an exclusively protective mechanism of the organism, is capable of becoming a factor of aggression against its own tissues under the influence of microbes expressing tissue antigens of mimicry.

KEY WORDS: generalized periodontitis, microorganisms, mimicry antigens, giardiasis.

Рукопис надійшов до редакції 19.12.2016

Відомості про автора: Савельєва Наталія - к. мед. наук, доцент касредри стоматології Харківського національного медичного університету , тел. 0505019172 